\title{
The evaluation of serum Adropin and Lipocalin levels in women with polycystic ovary syndrome
}

\author{
Polikistik over sendrom tanılı hastalarda Adropin ve Lipokalin düzeylerinin incelenmesi
}

\author{
Soner Gök, İ. Veysel Fenkci, Erkan Alataş, M. Babür Kaleli, Yaşar Enli
}

Gönderilme tarihi:05.10.2021

Kabul tarihi:26.11.2021

\section{Abstract}

Purpose: Polycystic Ovary Syndrome (PCOS) is related to metabolic diseases such as endothelial dysfunction, systemic inflammation, insulin resistance and dyslipidemia. Adropin is a peptide secretion that positively affects glucose homeostasis and hepatic steatosis in patients with PCOS. Lipocalin-2 mediates obesity, insulin resistance, and apoptosis induced by IL-3. The levels of adropin and lipocalin-2 in PCOS patients were studied in this study.

Materials and methods: Women with PCOS $(n=37)$ and healthy controls $(n=34)$ were assessed in this observational and cross-sectional study. Anthropometric measurements, demographic data, metabolic and hormonal profiles, Adropin and Lipocalin-2 levels were measured in both groups.

Results: In the study it was determined that in PCOS group Adropin and Lipocalin-2 levels were significantly reduced. LDL-C cholesterol, Total cholesterol, Total testosterone, LH, FAI, Triglyceride and LH/FSH values and hirsutism score were considerably lower in the control group than the PCOS group.

Conclusion: The fact that adropin levels were significantly reduced in PCOS patients who had not yet developed insulin resistance or who could not be detected using existing methods suggests that adropin changes in PCOS are insulin independent. Low Lipocalin-2 levels in patients with PCOS suggest that this cannot be blamed for insulin receptor dysfunction secondary to apoptosis in PCOS.

Key words: Adropin, lipocalin, insulin, polycystic ovary syndrome.

Gok S, Fenkci IV, Alatas E, Kaleli MB, Enli Y. The evaluation of serum Adropin and Lipocalin levels in women with polycystic ovary syndrome. Pam Med J 2022;15:141-147.

\section{Öz}

Amaç: Polikistik Over Sendromu (PKOS) metabolik bozukluklarla ilişkilidir. Bunlar özellikle endotel disfonksiyonu, insülin direnci, sistemik inflamasyon ve dislipidemi olarak belirtilmiştir. PKOS'lu hastalarda glikoz homeostazı ve hepatik steatozu olumlu bir biçimde etkileyen peptit yapılı bir salgı 'adropin' olarak adlandırılır. Lipokalin-2 apoptoziste aracı rolü üstlenmekte ve IL-3, obezite, insülin direnci tarafından uyarılmaktadır. Bu araştırmada PKOS'lu hastalarda adropin ve lipokalin-2 seviyeleri araştırılmıştır.

Gereç ve yöntem: Bu çalışmada hastalar 18-38 yaş aralığında PKOS tanısı almış $(n=37)$ ve sağlıklı kadın kontrol grubu $(n=34)$ olarak sınıflandırıldı. Her iki grupta demografik veriler, metabolik ve hormonal değerler, antropometrik ölçümler, serum Lipokalin-2 ve Adropin seviyeleri ölçüldü.

Bulgular: Araştırmada PKOS'lu hasta grubunda Lipokalin-2 ve Adropin düzeylerindeki düşüşün anlamlı olduğu bulunmuştur. Kontrol grubunda LDL-C kolesterol, Total kolesterol, Total testosteron, LH, FAI, Trigliserit ve LH/ FSH değerleri ve hirsutizm skoru PKOS grubuna göre daha düşük seviyelerde saptanmıştır.

Sonuç: Adropinin PKOS'ta insülinden bağımsız olarak farklılaşması PKOS'lu hastalarda insülin direnci tespiti ve gelişimi ortaya konulmadan adropin düzeylerindeki anlamlı azalmayı açıklamaktadır. Çalışma insulin direncinin patolojik seviyelere gelmeden adropin düzeyinin anlamlı olarak azaldığını ve bu durumun popülasyonun genç olması ile ilişkili olduğunu göstermektedir. PKOS'da apoptozise ikincil insülin reseptör fonksiyon bozukluğunun Lipokalin-2 seviyeleri ile ilişkili olmadığı ve bunun nedeninin PKOS'lu hastalarda Lipokalin-2 seviyelerinin düşük olmasından kaynaklandığı vurgulanmaktadır.

Anahtar kelimeler: Adropin, lipokalin, insulin, polikistik over sendromu.

Gök S, Fenkci IV, Alataş E, Kaleli MB, Enli Y. Polikistik over sendrom tanılı hastalarda Adropin ve Lipokalin düzeylerinin incelenmesi. Pam Tıp Derg 2022;15:141-147.

Soner Gök, Ass. Prof. M.D. Departments of Obstetrics and Gynecology, Pamukkale University, School of Medicine, Denizli, Turkey, e-mail: sonerrgok@hotmail.com (https://orcid.org/0000-0001-8940-1879) (Corresponding Author)

I. Veysel Fenkci, Prof. M.D. Departments of Obstetrics and Gynecology, Pamukkale University, School of Medicine, Denizli, Turkey, e-mail: veyselfenkci@yahoo.com (https://orcid.org/0000-0003-4929-5252)

Erkan Alataş, Prof. M.D. Departments of Obstetrics and Gynecology, Pamukkale University, School of Medicine, Denizli, Turkey, e-mail: erkanalatas@ hotmail.com (https://orcid.org/0000-0001-6423-5106)

M. Babür Kaleli, Prof. M.D. Departments of Obstetrics and Gynecology, Pamukkale University, School of Medicine, Denizli, Turkey, e-mail: bkaleli@aol.com (https://orcid.org/0000-0002-5122-9329)

Yaşar Enli, Prof. M.D. Departments of Biochemistry, Pamukkale University, School of Medicine, Denizli, Turkey, e-mail: yenli@pau.edu.tr (https://orcid.org/0000-0001-5080-3192) 


\section{Introduction}

Polycystic ovary syndrome (PCOS) is a syndrome consisting of the combination of menstrual phase defect such as amenorrhea and oligomenorrhea, biochemical and/or clinical findings of hyperandrogenemia, and the appearance of polycystic ovary (PCO) detected by ultrasonography. It is a major endocrinological condition that affects women during their reproductive years. It is first identified in the early reproductive years due to hormonal changes [1, 2].

The prevalence of PCOS varies according to the criteria used in the definition. According to a meta-analysis, the rate of PCOS was $6 \%$ using the National Institutes of Health (NIH) criteria; It was found to be $10 \%$ when the Rotterdam criteria were used, and $10 \%$ when the Androgen Excess and PCOS (AE-PCOS) Society criteria were used [3]. According to a study conducted in Turkey in 2012, the prevalence of PCOS is 6.1 percent, 19.9 percent, and 15.3 percent, respectively, according to the ' $\mathrm{NIH}$, Europian Society of Human Reproduction and Embryology (ESHRE)-American Society for Reproductive Medicine (ASRM)-Rotterdam, and Androgen Excess Society criteria' [4].

Polycystic ovary, chronic anovulation, and hyperandrogenism are hallmarks of PCOS. Insulin resistance, hypertension, hyperinsulinemia, abdominal obesity, and dyslipidemia are all symptoms of PCOS, as are long-term significant repercussions such endometrial hyperplasia, coronary artery disease and type 2 diabetes [5]. They also stated that even if a woman is genetically susceptible to the development of PCOS, it is the combination of hereditary and environmental variables (obesity) with genetic factors that cause PCOS to occur [6].

Adropin is a peptide hormone that plays a role in energy homeostasis and maintains glucose and fatty acid metabolism [7, 8]. Adropin has been shown to regulate the expression of hepatic lipogenic genes and the PPAR receptor (peroxisome proliferator-activated receptor-gamma), both of which are involved in lipogenesis [9]. It is estimated that the plasma adropin concentration ranges from 1 to $10 \mathrm{ng} /$ $\mathrm{mL}$ [10]. However, adropin levels can change in various physiological and pathophysiological conditions.

Adiponectin and visfatin, two adipocytokines generated from adipose tissue, have exhibited insulin-sensitizing action [11]. Also, lipocalin-2 is an adipocytokine. In studies, decreased glucose tolerance, insulin sensitivity, and synthesis, and the pancreatic beta-cell count was observed in Lipocalin-2 osteoblast-negative mice (white adipose tissue is not negative), while increased food intake and weight gain were observed in Lipocalin-2 negative (non-osteoblast-negative) mice in adipose tissue [12]. Different results have been revealed in studies on the disorders related to PCOS and insulin resistance of lipocalin levels. For these results, the potential mechanism has not been fully explained [13$17]$.

Investigation of whether serum Adropin and Lipocalin-2 levels are related with insulin resistance, visceral obesity, and dyslipidemia in women with PCOS is important to reveal the pathophysiology of PCOS. In this study, Adropin and Lipocalin-2 serum levels were investigated in patients with PCOS compared to healthy women in the control group and their correlation with insulin resistance. Investigation of possible underlying mechanisms will help to understand the pathophysiology of PCOS and to identify new therapeutic targets.

\section{Materials and methods}

\section{Subjects}

The study included 37 patients diagnosed with PCOS (ages of 18-38) and 34 healthy women (ages of 18-38) who applied to our Gynecology and Obstetrics Clinic. The diagnosis of PCOS is approved by the international evidence-based guidelines for the evaluation and management of PCOS including The Rotterdam criteria in women who have at least two of the following symptoms; ovarian dysfunction (oligo-amenorrhea), biochemical and/or clinical hyperandrogenism, enlarged polycystic ovaries. In the control group, there are healthy female subjects of reproductive age with regular menstrual cycles (2-7 days with 25-34-day periods). Patients with diabetes mellitus, androgen-secreting tumors, Cushing's syndrome and infectious diseases, hypertension, 
endocrinopathy (late-onset 21-hydroxylase defect), thyroid dysfunction, chronic liver disease, drug that affects or alters insulin secretion and function, hyperprolactinemia, sex hormones and lipid profile users, alcohol and cigarette users were not included in the study. The local medical ethics committee authorized this research and informed consent form had been signed by all participants before the study.

\section{Biochemical analysis}

In all cases, 3-5 days of spontaneous or progesterone-induced cycles venous blood samples were received after 12 hours of fasting. Serum fasting glucose (FG), dehydroepiandrosterone sulfate (DHEAS), total cholesterol (TC), insulin, triglyceride (TG), sex hormone-binding globulin (SHBG), luteinizing hormone (LH), total testosterone, high density lipoprotein cholesterol (HDL), follicle-stimulating hormone (FSH), Adropin, and Lipocalin-2 levels were studied.

LDL levels were measured using the Friedewald formula. The following formula was used for non-HDL levels: Non-HDL=Total cholesterol - HDL.

Free androgen index (FAI) was calculated with the formula $[\mathrm{FAl}=100 \mathrm{X}$ total testosterone (in $\mathrm{nmol} / \mathrm{L}$ )/SHBG (in $\mathrm{nmol} / \mathrm{L}$ )].

The "homeostasis model assessment (HOMA-IR)" score [fasting insulin concentration (mIU/L) X glucose (mmol/L)/22.5] was used to detect insulin resistance.

\section{Anthropometric measurements}

Body mass index (BMI) $\left(\mathrm{kg} / \mathrm{m}^{2}\right)$ and waisthip ratio was calculated by measuring the waist and hip circumferences of the subjects on the day the serum samples were taken.

\section{Statistical analysis}

In the analysis of the data within the scope of the research, descriptive and descriptive statistical methods were used by using the SPSS 17.0 (Statistical Package for the Social Science) package program. The evaluation of the data was made at the $95 \%$ confidence interval and at the $p<0.05$ significance level. Data were expressed as mean \pm standard error ( \pm SE). Since normal "Gaussian" distribution was observed in many parameters studied, the "T-test" method, which is a parametric method. The correlation analysis between the parameters was calculated with the "Pearson's Correlation Coefficient".

\section{Results}

Hirsutism score was found to be lower in the control group than in the PCOS group $(p<0.05)$. There was no difference in age, BMI, weight, waist/hip and waist circumference ratios between the PCOS group and the control group $(p>0.05)$ (Table 1).

It was found that HOMA-IR and insulin levels did not differ between PCOS and control groups $(p>0.05)$ (Table 2).

Total cholesterol, LDL-C, Total testosterone, Triglyceride, LH, FAI and LH/FSH levels were higher in the PCOS patient group than in the control group $(p<0.05)$. Adropin and lipocalin-2 levels were statistically considerably decreased in the PCOS patient group compared to the control group $(p<0.05)$ (Table 2$)$.

There was a positive correlation between HOMA-IR levels and insulin $(r=0.989 p=0.001)$, BMI $(r=0.294 p=0.013)$ and triglyceride $(r=0.407$ $p=0.001$ ) levels. There was a positive correlation between $\mathrm{FAl}$ levels and LH/FSH $(r=0.333$ $p=0.005)$ and Triglyceride ( $r=0.354 p=0.002)$ levels. There was a negative correlation between FAl levels and HDL ( $r=-0.348 p=0.003)$ levels. There was a positive correlation between the waist/hip ratio and $\mathrm{BMI}(\mathrm{r}=0.444 p=0.001)$. There was a positive correlation between insulin levels and Triglyceride $(r=0.427 p=0.001)$ and between insulin levels and BMI $(r=0.315$ $p=0.007)$. There was a positive correlation between total cholesterol levels and TG $(r=0.373$ $p=0.001)$, LDL $(r=0.852 p=0.001)$ and BMI $(r=0.339 p=0.004)$ levels. There was a positive correlation between triglyceride levels and LDL $(r=0.299 p=0.011)$ and BMI $(r=0.314 p=0.008)$. There was a negative correlation between triglyceride and HDL ( $r=-0.498 p=0.001)$ levels. There was a negative correlation between HDL levels and LDL $(r=-0.274 p=0.021)$ and BMI $(r=-$ $0.281 p=0.018$ ). There was a positive correlation between LDL levels and BMI ( $r=0.423 p=0.001)$ (Table 3). 
Table 1. Demographic and anthropometric measurements of the patient and control groups

\begin{tabular}{llll}
\hline Variable & $\begin{array}{l}\text { Women with PCOS } \\
(\mathrm{n}=37)\end{array}$ & $\begin{array}{l}\text { Healty control } \\
(\mathrm{n}=34)\end{array}$ & $p^{*}$ \\
\hline Age (year) & $22.14 \pm 0.69$ & $24.26 \pm 0.84$ & 0.054 \\
Weight $(\mathrm{kg})$ & $60.43 \pm 1.88$ & $59.32 \pm 1.69$ & 0.665 \\
Hirsutism score & $9,86 \pm 0.19$ & $4.32 \pm 0.10$ & $0.001^{*}$ \\
BMI $\left(\mathrm{kg} / \mathrm{m}^{2}\right)$ & $22.62 \pm 0.67$ & $22.43 \pm 0,56$ & 0.883 \\
$\begin{array}{l}\text { Waist circumference } \\
(\mathrm{cm})\end{array}$ & $80.54 \pm 2.38$ & $78.20 \pm 1.91$ & 0.453 \\
Waist/Hip & $0.80 \pm 0.01$ & $0.80 \pm 0.01$ & 0.811 \\
\hline
\end{tabular}

*: $p<0.05$ Statistically significant

Table 2. Biochemical characteristics of the patient and control groups

\begin{tabular}{llll}
\hline Variable & Women with PCOS $(\mathrm{n}=37)$ & Healty control $(\mathrm{n}=34)$ & $p^{*}$ \\
\hline SFG $(\mathrm{mg} / \mathrm{dL})$ & $88.51 \pm 1.82$ & $88.20 \pm 1.72$ & 0.903 \\
Insulin (mIU/ml) & $12.02 \pm 1.36$ & $9.32 \pm 0.85$ & 0.105 \\
HOMA-IR & $2.73 \pm 0.34$ & $2.04 \pm 0.19$ & 0.096 \\
TC(mg/dL) & $173.81 \pm 4.17$ & $151.38 \pm 4.01$ & $0.001^{*}$ \\
HDL-C (mg/dL) & $57.02 \pm 2.50$ & $59.50 \pm 2.26$ & 0.469 \\
LDL-C (mg/dL) & $97.83 \pm 4.41$ & $79.61 \pm 3.39$ & $0.002^{*}$ \\
TG (mg/dL) & $100.72 \pm 8.84$ & $63.00 \pm 4.68$ & $0.001^{*}$ \\
Total testosterone (ng/ml) & $0.35 \pm 0.02$ & $0.27 \pm 0.02$ & $0.018^{*}$ \\
SHBG (nmol/L) & $28.34 \pm 3.51$ & $34.96 \pm 3.07$ & 0.164 \\
DHEAS & $272.89 \pm 17.6$ & $240.10 \pm 15.05$ & 0.166 \\
FAl & $6.65 \pm 0.99$ & $3.66 \pm 0.54$ & $0.012^{*}$ \\
FSH (mlU/mL) & $5.75 \pm 0.21$ & $6.39 \pm 0.33$ & 0.102 \\
LH (mIU/mL) & $10.26 \pm 0.75$ & $5.46 \pm 0.26$ & $0.001^{*}$ \\
LH/FSH & $1.81 \pm 0.12$ & $0.88 \pm 0.04$ & $0.001^{*}$ \\
Adropin (ng/mL serum) & $4.18 \pm 0.27$ & $10.08 \pm 1.79$ & $0.001^{*}$ \\
Lipocalin (ng/mL serum) & $254.61 \pm 8.87$ & $280.83 \pm 5.78$ & $0.018^{*}$ \\
\hline
\end{tabular}

*: $p<0.05$ Statistically significant SFG: Serum Fasting Glucose

HOMA-IR: Homeostasis Model Assessment, TC: Total Cholesterol

HDL-C: High-Density Lipoprotein-Cholesterol, LDL-C: Low-Density Lipoprotein-Cholesterol

TG: Trigliserit, SHBG: Sex Hormone-Binding Globulin, DHEAS: Dehydroepiandrosterone Sulfate

FAl: Free Androgen Index, FSH: Follicle-Stimulating Hormone, LH: Luteinizing Hormone 
Table 3. Correlation levels between variables

\begin{tabular}{|c|c|c|c|c|c|c|c|c|c|c|}
\hline & & $\mathrm{FAl}$ & Waist/Hip & Insulin & $\mathrm{TC}$ & TG & HDL-C & LDL-C & BMI & $\mathrm{LH} / \mathrm{FSH}$ \\
\hline \multirow{2}{*}{ HOMA-IR } & $r$ & 0.135 & 0.089 & $.989^{* *}$ & 0.115 & $.407^{* *}$ & -0.127 & 0.030 & $.294^{*}$ & 0.195 \\
\hline & $p$ & 0.262 & 0.463 & 0.000 & 0.340 & 0.000 & 0.293 & 0.801 & 0.013 & 0.103 \\
\hline \multirow{2}{*}{ FAI } & $r$ & 1 & 0.148 & 0.129 & 0.067 & $.354^{* *}$ & $-.348^{* *}$ & 0.129 & 0.082 & $.333^{* *}$ \\
\hline & $p$ & & 0.218 & 0.282 & 0.578 & 0.002 & 0.003 & 0.283 & 0.497 & 0.005 \\
\hline \multirow{2}{*}{ Waist/Hip } & $r$ & & 1 & 0.112 & 0.132 & 0.059 & -0.072 & 0.145 & $.444^{* *}$ & -0.101 \\
\hline & $p$ & & & 0.352 & 0.271 & 0.623 & 0.552 & 0.228 & 0.000 & 0.401 \\
\hline \multirow{2}{*}{ Insulin } & $r$ & & & 1 & 0.111 & $.427^{* *}$ & -0.149 & 0.034 & $.315^{* *}$ & 0.178 \\
\hline & $p$ & & & & 0.358 & 0.000 & 0.216 & 0.777 & 0.007 & 0.137 \\
\hline \multirow{2}{*}{ TC } & $r$ & & & & 1 & $.373^{* *}$ & 0.116 & $.852^{* *}$ & $.339^{* *}$ & 0.130 \\
\hline & $p$ & & & & & 0.001 & 0.336 & 0.000 & 0.004 & 0.280 \\
\hline \multirow{2}{*}{ TG } & $r$ & & & & & 1 & $-.498^{* *}$ & $.299^{*}$ & $.314^{* *}$ & 0.054 \\
\hline & $p$ & & & & & & 0.000 & 0.011 & 0.008 & 0.655 \\
\hline \multirow{2}{*}{ HDL-C } & $r$ & & & & & & 1 & $-.274^{*}$ & $-.281^{*}$ & 0.115 \\
\hline & $p$ & & & & & & & 0.021 & 0.018 & 0.341 \\
\hline \multirow{2}{*}{ LDL-C } & $r$ & & & & & & & 1 & $.423^{* *}$ & 0.082 \\
\hline & $p$ & & & & & & & & 0.000 & 0.498 \\
\hline \multirow{2}{*}{ BMI } & $r$ & & & & & & & & 1 & -0.153 \\
\hline & $p$ & & & & & & & & & 0.203 \\
\hline
\end{tabular}

*: $p<0.05,{ }^{* *}: p<0.001$ Statistically significant HOMA-IR: Homeostasis Model Assessment

TC: Total Cholesterol HDL-C: High-Density Lipoprotein-Cholesterol

LDL-C: Low-Density Lipoprotein-Cholesterol, TG: Trigliserit

FAl: Free Androgen Index, FSH: Follicle-Stimulating Hormone LH: Luteinizing Hormone

\section{Discussion}

PCOS is a common endocrine disorder, affecting $6-18 \%$ of women of reproductive age. It is generally associated with obesity, insulin resistance (IR), increased prevalence of type II diabetes (T2DM) and hyperlipidemia. The precise mechanism underlying PCOS has not yet been elucidated [18]. In this study, the relationship between serum adropin and lipocalin-2 levels and insulin resistance was investigated in healthy women with PCOS. Total cholesterol, Triglyceride, LDL-C, Total testosterone, LH, LH/FSH and FAl levels were found to differ between the PCOS group and the control group. In the study, it was found that adropin levels were lower in women with PCOS than in healthy women, and it was statistically significant. It has also been reported in previous studies that serum adropin levels are lower in women with PCOS [19-22]. Kuliczkowska Płaksej et al. [23] reported that PCOS patients had lower serum adropin levels, but there was no statistically significant result in comparison with the healthy and patient groups. In the study, it was revealed that this result was due to the small sample size. According to Hamdi et al. [24] reported that women with PCOS had lower serum adropin levels. The results of the study are compatible with the literature.

According to Yildirim et al. [19] there was a negative relationship between adropin and HOMA-IR, fasting insulin levels, and total cholesterol. A research was stated that there was a negative correlation between andropin with HOMA-IR, fasting insulin, total cholesterol, glucose levels, BMI, and LDL levels [20].

Lipocalin-2 levels were found lower in women with PCOS, and statistical differences were found between PCOS and the control group in this study. Gencer et al. [15] stated that lipocalin-2 level were considerably lower in women with PCOS. Diamanti Kandarakis et al. [25] reported that circulating lipocalin-2 levels were found to be quite low in women with PCOS and this was not related with insulin resistance, obesity, and estradiol levels. On the other hand, Çakal et al. [17] stated that lipocalin-2 levels were higher in women with PCOS compared to the 
control. In the study of Yılmaz et al. [26] noticed that lipocalin-2 levels were higher in women with PCOS. When the literature is examined, seen that there is a difference between the results of the study. This difference is thought to be due to the structure of the sample group studied.

The fact that adropin levels were significantly decreased in PCOS patients where insulin resistance has not been developed yet or could not be detected by current methods indicates that adropin changes independently of insulin in PCOS. Accordingly, adropin is a biomarker for PCOS. Observation of low Lipocalin-2 levels in PCOS patients without obesity and insulin resistance suggests that this cannot be held responsible for insulin receptor dysfunction secondary to apoptosis in PCOS.

Conflict of interest: No conflict of interest was declared by the authors.

\section{References}

1. Fauser BCJM, Tarlatzis BC, Rebar RW, et al. Consensus on women's health aspects of polycystic ovary syndrome (PCOS): the Amsterdam ESHRE/ASRM-Sponsored 3rd PCOS Consensus Workshop Group. Fertil Steril 2012;97:28-38. https://doi.org/10.1016/j.fertnstert.2011.09.024

2. Bhide P, Homburg R. Anti-Müllerian hormone and polycystic ovary syndrome. Best Pract Res Clin Obstet Gynaecol 2016;37:38-45. https://doi.org/10.1016/j.bpobgyn.2016.03.004

3. Bozdag G, Mumusoglu S, Zengin D, Karabulut E, Yildiz BO. The prevalence and phenotypic features of polycystic ovary syndrome: a systematic review and meta-analysis. Hum Reprod 2016;31:2841-2855. https://doi.org/10.1093/humrep/dew218

4. Yildiz BO, Bozdag G, Yapici Z, Esinler I, Yarali H. Prevalence, phenotype and cardiometabolic risk of polycystic ovary syndrome under different diagnostic criteria. Hum Reprod 2012;27:3067-3073. https://doi.org/10.1093/humrep/des232

5. Bellver J, Rodríguez Tabernero L, Robles A, et al. Polycystic ovary syndrome throughout a woman's life. J Assist Reprod Genet 2018;35:25-39. https://doi.org/10.1007/s10815-017-1047-7

6. Kshetrimayum C, Sharma A, Mishra VV, Kumar S. Polycystic ovarian syndrome: Environmental/occupational, lifestyle factors; an overview. J Turk Ger Gynecol Assoc 2019;20:255-263. https://doi.org/10.4274/jtgga.galenos.2019.2018.0142

7. Marczuk N, Cecerska Heryć E, Jesionowska A, Dołęgowska B. Adropin - physiological and pathophysiological role. Postepy Hig Med Dosw (Online) 2016;70:981988. https://doi.org/10.5604/17322693
8. Gao S, McMillan RP, Zhu Q, Lopaschuk GD, Hulver MW, Butler AA. Therapeutic effects of adropin on glucose tolerance and substrate utilization in diet-induced obese mice with insulin resistance. Mol Metab 2015;4:310-324. https://doi.org/10.1016/j.molmet.2015.01.005

9. Ganesh Kumar K, Trevaskis JL, Lam DD, et al. Identification of adropin as a secreted factor linking dietary macronutrient intake with energy homeostasis and lipid metabolism. Cell Metab 2008;8:468-481. https://doi.org/10.1016/j.cmet.2008.10.011

10. Aydin S, Kuloglu T, Aydin S. Copeptin, adropin and irisin concentrations in breast milk and plasma of healthy women and those with gestational diabetes mellitus. Peptides 2013;47:66-70. https://doi.org/10.1016/j.peptides.2013.07.001

11. Wang $\mathrm{Y}$, Lam KSL, Kraegen EW, et al. Lipocalin-2 is an inflammatory marker closely associated with obesity, insulin resistance, and hyperglycemia in humans. Clin Chem 2007;53:34-41. https://doi.org/10.1373/clinchem.2006.075614

12. Mosialou I, Shikhel S, Liu JM, et al. MC4R-dependent suppression of appetite by bone-derived lipocalin 2. Nature 2017;543:385-390. https://doi.org/10.1038/nature21697

13. Panidis D, Tziomalos K, Koiou E, et al. The effects of obesity and polycystic ovary syndrome on serum lipocalin-2 levels: a cross-sectional study. Reprod Biol Endocrinol 2010;8:151. https://doi.org/10.1186/1477-7827-8-151

14. Esteve E, Ricart W, Fernández Real JM. Adipocytokines and insulin resistance: the possible role of lipocalin-2, retinol binding protein-4, and adiponectin. Diabetes Care 2009;32:362-367. https://doi.org/10.2337/dc09-S340

15. Gencer M, Gazi E, Hacıvelioğlu S, et al. The relationship between subclinical cardiovascular disease and lipocalin-2 levels in women with PCOS. Eur J Obstet Gynecol Reprod Biol 2014;181:99-103. https://doi.org/10.1016/j.ejogrb.2014.07.032

16. Koiou E, Tziomalos K, Katsikis I, et al. Weight loss significantly reduces serum lipocalin-2 levels in overweight and obese women with polycystic ovary syndrome. Gynecol Endocrinol 2012;28:20-24. https://doi.org/10.3109/09513590.2011.588745

17. Cakal E, Ozkaya M, Engin Ustun Y, Ustun Y. Serum lipocalin-2 as an insulin resistance marker in patients with polycystic ovary syndrome. J Endocrinol Invest 2011;34:97-100. https://doi.org/10.1007/BF03347037

18. Hu L, Shen H, Wu QF, Tian L, Hu MH. Treatment of polycystic ovarian syndrome with insulin resistance by insulin-sensitizer. Clin Exp Obstet Gynecol 2014;41:288292. 
19. Yildirim B, Celik O, Aydin S. Adropin: a key component and potential gatekeeper of metabolic disturbances in policystic ovarian syndrome. Clin Exp Obstet Gynecol 2014;41:310-312.

20. Kume T, Calan M, Yilmaz O, et al. A possible connection between tumor necrosis factor alpha and adropin levels in polycystic ovary syndrome. J Endocrinol Invest 2016;39:747-754. https://doi.org/10.1007/s40618-016-0453-5

21. Ozturk Inal Z, Erdem S, Gederet $Y$, et al. The impact of serum adropin and ischemia modified albumin levels based on BMI in PCOS. Endokrynol Pol 2018;69:135141. https://doi.org/10.5603/EP.a2018.0002

22. Sen H, Erbag G, Bınnetoglu E, et al. Adropin levels in polycystic ovary syndrome patients. J Clin Anal Med 2017;8:23-26. https://doi.org/10.4328/jcam.4508

23. Kuliczkowska Płaksej J, Mierzwicka A, Jończyk M, Stachowska B, Urbanovych A, Bolanowski M. Adropin in women with polycystic ovary syndrome. Endokrynol Pol 2019;70:151-156. https://doi.org/10.5603/EP.a2018.0092

24. Hamdi RA, Abas HN, Alsaeed FAA. Role of adropin in women with polycystic ovary syndrome. Scopus ljphrd Citation Score 2019;10:291-296.

25. Diamanti Kandarakis E, Livadas S, Kandarakis SA, Margeli A, Papassotiriou I. Serum concentrations of atherogenic proteins neutrophil gelatinaseassociated lipocalin and its complex with matrix metalloproteinase- 9 are significantly lower in women with polycystic ovary syndrome: hint of a protective mechanism?. Eur J Endocrinol 2008;158:525-531. https://doi.org/10.1530/EJE-07-0822

26. Yilmaz $\mathrm{O}$, Temur $\mathrm{M}$, Calan $\mathrm{M}$, et al. The relationship between lipocalin-2 and free testosterone levels in polycystic ovary syndrome. Endokrynol Pol 2017;68:712. https://doi.org/10.5603/EP.2017.0002

Ethics committee approval: Pamukkale University, Non-Invasive Clinical Trials Ethics Committee, approval date: 03.12.2013, approval number: 16.

\section{Contributions of the authors to the article}

S.G. and I.V.F. constructed the main idea and hypothesis of study. S.G., I.V.F., E.A. and B.K. developed the theory and organized the material method section. S.G., I.V.F. and Y.E. made the evaluation of data in results section. Discussion section of the article written by S.G., E.A., B.K. and I.V.F. has reviewed and made the necessary corrections and approved. In addition, all authors discussed the entire study and confirmed its final version. 